\title{
The effect of interval and continuous training on the content of perilipin 1, ATGL and CGI-58 in visceral adipose tissue of obese male rats
}

\author{
Faridnia $\mathbf{M}^{1}$, Mohebbi $\mathbf{H}^{2}$, Khalafi $\mathbf{M}^{1}$, Moghaddami $\mathrm{K}^{1}$ \\ 1. PhD Student, Department of Exercise Physiology, Faculty of Physical Education and Sport Sciences, University of \\ Guilan, Rasht, Iran. \\ 2. Professor, Department of Exercise Physiology, Faculty of Physical Education and Sport Sciences, University of Guilan, \\ Rasht, Iran, (Correspondence Author) Tel: +98-26-34474361, Email: h_mohebbi@yahoo.com
}

\begin{abstract}
Background and Aim: Obesity is an excessive accumulation of fat and its storage due to an imbalance between energy intake and energy consumption. High-fat diets, through inhibition of lipolysis enzymes can lead to increase in obesity and also many metabolic diseases. While exercise can activate these enzymes and lead to a change in the amount of visceral adipose tissue and reduce obesity. The purpose of this study was to investigate the effect of high intensity interval training (HIIT) and moderate intensity continuous training (MICT) on the content of perilipin 1, ATGL, and CGI-58 in visceral adipose tissue of obese male rats.

Material and Methods: Forty male Wistar rats were divided into five groups of eight. A group of 8 rats consumed standard diet (SD) for 10 weeks, and 32 other rats used high-fat diet (HFD) for 10 weeks. After induction of obesity, 8 rats from high fat diet group and 8 rats from standard dietary group were killed, and the samples were collected to study the effects of high-fat diet. Other obese rats were randomly divided into three groups: high-fat diet sedentary (HFD+SED), moderate-intensity continuous training protocol (MICT), and highintensity interval training protocol (HIIT). The HIIT protocol consisted of 10 times of running, each time for 4 minutes, on a treadmill with an intensity of 90-85\% VO2max, with 2 minutes' active rest periods, and the MICT protocol included running on treadmill with an intensity of $70-65 \%$ VO2max, which had been_matched with the HIIT protocol in terms of distance. 5 sessions of The training scheduals were performed per week for 12 weeks. Finally, the samples were collected by western blot method to measure the content of perilipin 1, ATGL, CGI58.

Results: The results of this study showed that obesity caused a significant reduction in the content of prilipin 1 , ATGL and CGI-58. While both moderate-intensity continuous training and high-intensity interval training significantly increased the content of perilipin 1 and ATGL $(\mathrm{p} \leq 0.05)$. Also, the high-intensity interval training led to a significant increase in CGI-58 content $(\mathrm{p}<0.05)$. While moderate-intensity continuous training did not result in significant changes in CGI-58 protein content.

Conclusion: The findings of this study showed that high-fat diet resulted in increased fat mass, as well as weight gain and obesity. On the contrary, exercise trainings can lead to a decrease in fat mass and weight loss by increasing the proteins and enzymes effective in the lipolysis process.

Keywords: High intensity interval training, Moderate intensity continuous training, Perilipin 1, ATGL, CGI-58, Obesity.
\end{abstract}

Recevied: Aug 28, 2018

Accepted:Mar 29, 2019

How to cite the article: Faridnia M, Mohebbi H, Khalafi M, Moghaddami K, Khalafi M. The effect
of interval and continuous training on the content of perilipin 1, ATGL and CGI-58 in visceral
adipose tissue of obese male rats. SJKU 2019; 24 (1): 78-89.

Copyright (C) 2019 the Author (s). Published by Kurdistan University of Medical Sciences. This is an open access article distributed under the terms of the Creative Commons Attribution-Non Commercial License 4.0 (CCBY-NC), where it is permissible to download, share, remix, transform, and buildup the work provided it is properly cited. The work cannot be used commercially without permission from the journal. 


\section{اثر تمرينات تناوبى و تداومى بر محتواى بريليين ا، ATGL و CGI-58 بافت حربى احشايى

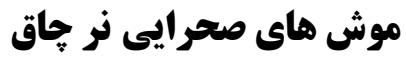

مهر سا فريدنيا '، حميد محبى '، موسى خلفى '، كاميليا مقدمى'

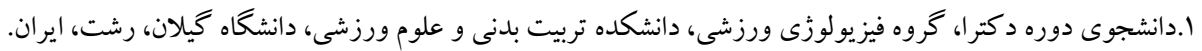

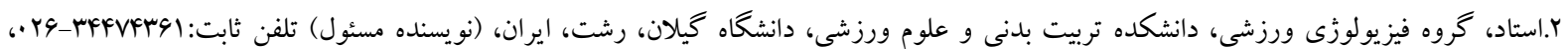
ايميل: h_mohebbi@yahoo.com

زمينه و هدف: جاقى تجمع بيش از حد جربى و ذخيره سازى آن به علت عدم تعادل بين انرزى دريافتى و انرزى مصرفى مى

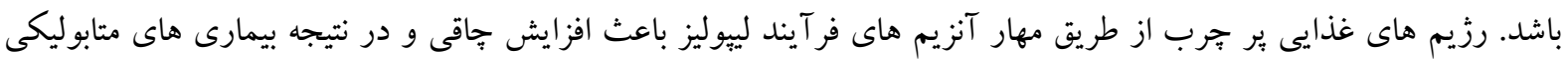
زيادى مى شوند. در حالى كه ورزش از طريق فعال كردن اين آنزيم ها مى تواند منجر به تغيير در مقدار بافت جربى احشايى و كاهش جاقى شود. هدف از تحقيق حاضر بررسى اثر تمرينات تناوبى با شدت بالا (HIIT) و تمرين تداومى با شدت متوسط

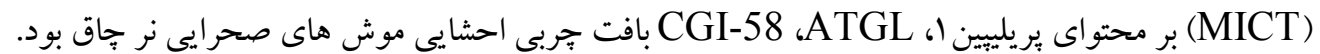

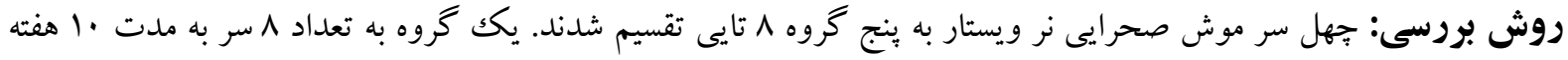

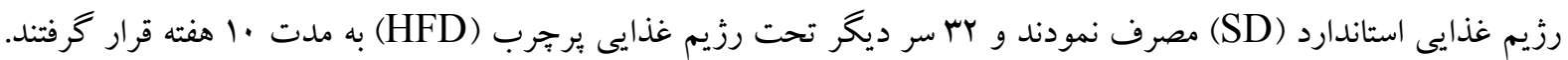

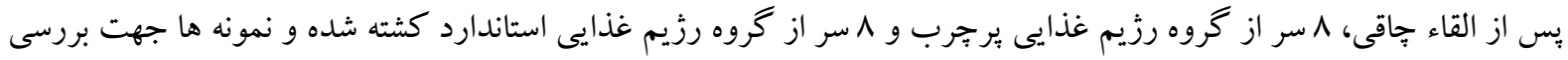

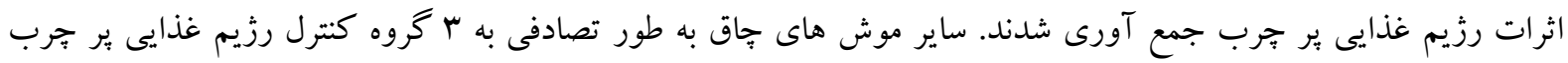

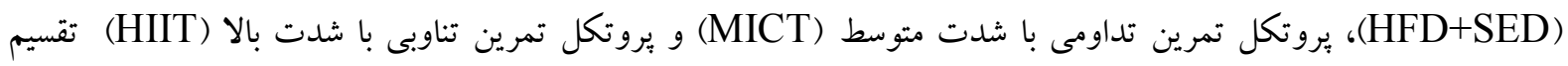

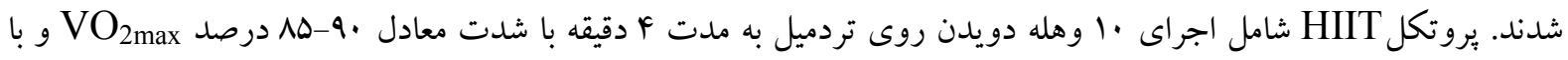

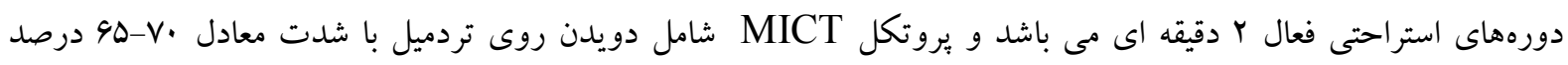

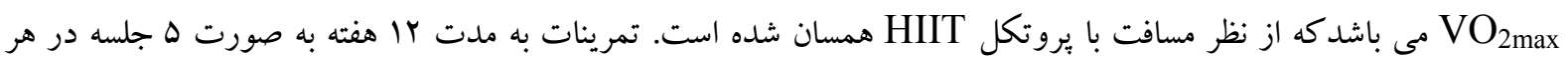

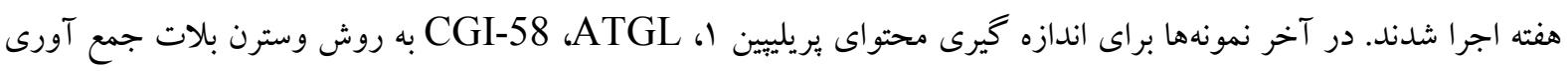

يافته ها: در اين تحقيق نشان داده شد كه جاقى منجر به كاهش معنى دار محتواى يروتئين هاى بريليبين ا، ATGL و CGI-^

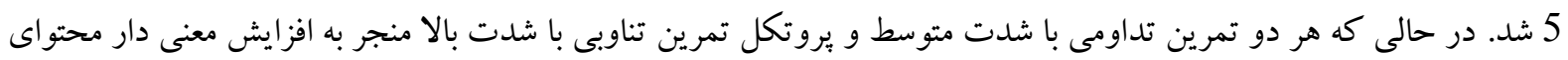

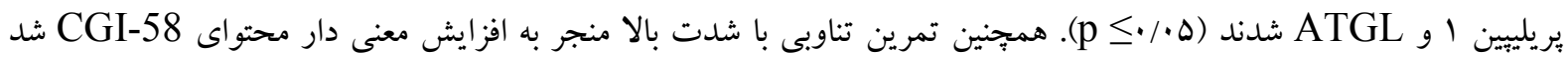

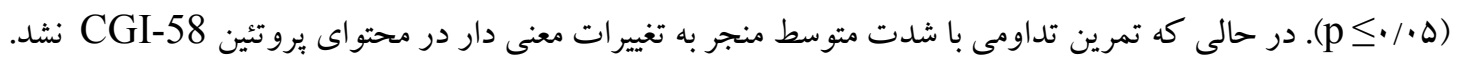
نتيجه عَيرى: يافنه هاى اين تحقيق نشان داد كه رزيم غذايى بر خرب منجر به افزايش توده جربى و همجنين افزايش وزن و جاقى مى شود. در مقابل نشان داده شد تمرينات ورزشى از طريق افزايش بروتئين ها و آنزيم هاى موثر در فر آيند لييوليز مى تواند منجر به كاهش توده جربى و كاهش وزن شود.

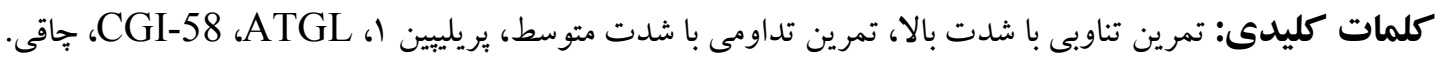

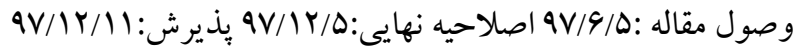


وابسته به قطرات خربى را در بافت جربى موش هاى

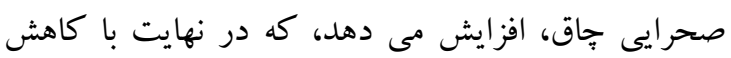
حجم جربى احشايى و اندازه قطرات جربى همراه است. جرا دهرا

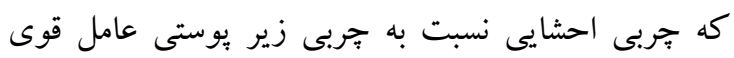

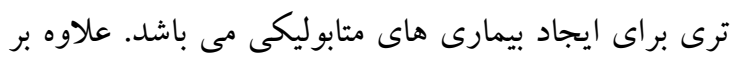

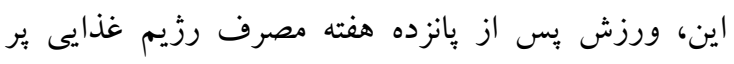
جرب با فعال كردن مسير كاتكولامين ها و افزايش سطوح

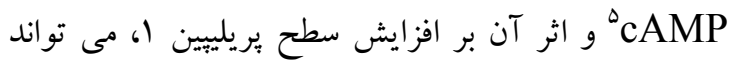

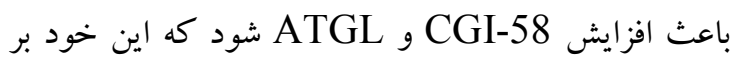
روند افزايش لييوليز و كاهش توده جربى اثر مثبت مى بـ

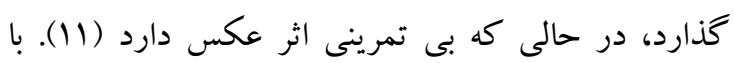
اينكه ساز گارىهاى متابوليكى با تمرينات تداومى اثبات

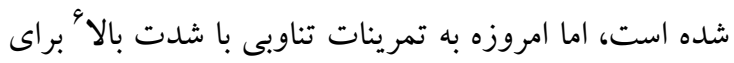

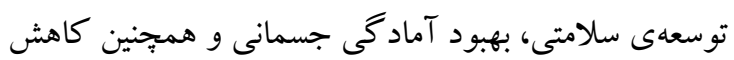
وزن توجه زيادى شده است. بر اين اساس، مطالعات اخير نشان دادهاند كه تمرينات تناوبى با شدت بالا ياستخ

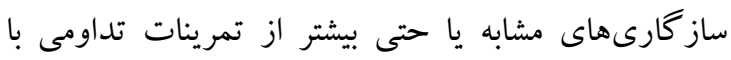

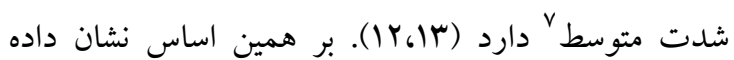
ATGL شده است كه تمرينات تناوبى با شدت بالا ميزان را از طريق افزايش تحريكات بتا آدرنرزيك افزايش مى دهد كه اين مى تواند بر افزايش روند لييوليز اثر كذار باشد. همجنين نشان داده شده كه اين تمرينات مى تواند با فعال

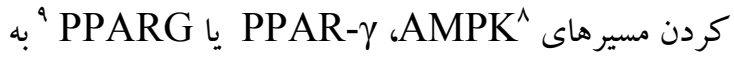
عنوان فعال كننده هاى مهم براى cAMP، و اثر آن بر

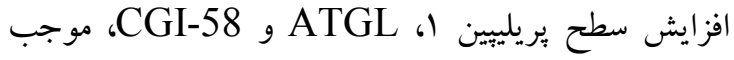

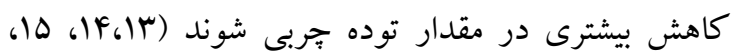
19). در تحقيقات انجام شده بيشتر اثر تمرينات تداومى بر

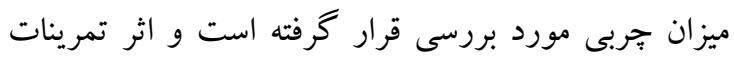

\footnotetext{
${ }^{5}$ Cyclic Adenosine Monophosphate

${ }^{6}$ High-intensity interval training

${ }^{7}$ Moderate Intensity Continuous Training

${ }^{8}$ adenosine monophosphate-activated protein kinase

${ }^{9}$ Peroxisome proliferator-activated receptor gamma
}

مقدمه

سبك زندگى كم تحرّك موجب بروز بيمارى هايى از جمله فشارخون بالا، جاقى، ديابت نوع دو، بيمارى هاى قلبى- عروقى، انواع خاصى از سرطان و اختلال هاى

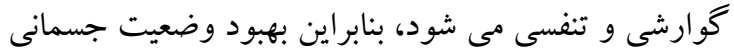

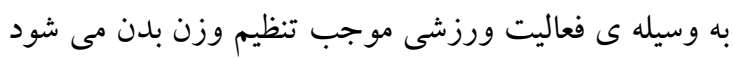

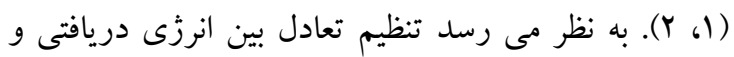
انرزى مصرفى منجر به ورود به مسيرهاى بيوزنز قطرات

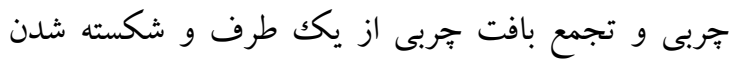
قطرات جربى از طرفى ديخر مى شود (r). مطالعات نشان

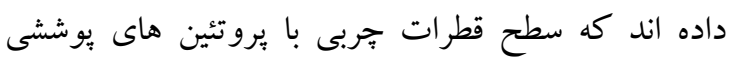

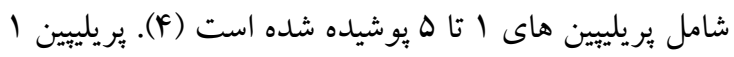

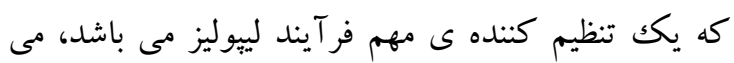

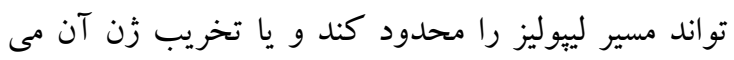
تواند منجر به كاهش جربى و افزايش سطوح پايه لييوليز

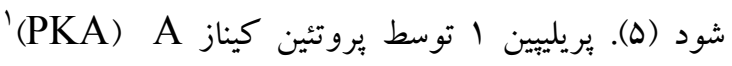
N- فسفريله مى شود. فسفريله شدن سه قسمت از پايانه ' Serin

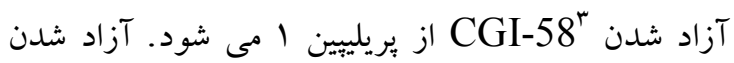

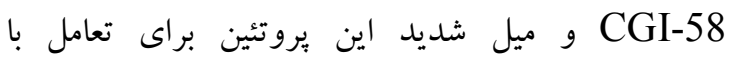

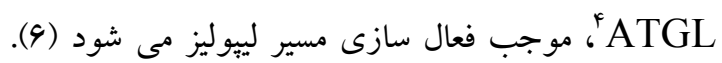

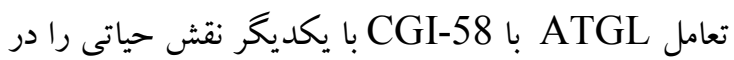
لييوليز و فرآيند هيدروليز ترى آسيل كليسيرول توسط

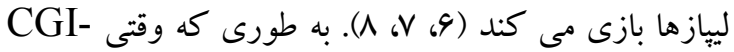
58 با ATGL تركيب شد، فعاليت هاى لييوليتيكى در مقايسه با ATGL به تنهايى به طور قابل ملاحظه افزايش مى يابد (9). ورزش براى بهبود جاقى راه حل مناسبى مى باشد زيرا لييوليز را فعال مى كند (•l). نشان داده شده كه توده جربى احشايى يس از بى تمرينى افزايش يافته است و

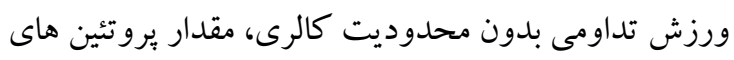

\footnotetext{
${ }^{1}$ Protein Kinase A

${ }^{2} \mathrm{~N}$-Serin terminal

${ }^{3}$ Comparative Gene Identification-58

${ }^{4}$ Adipose Tissue Triglyceride Lipase
} 
تصادفى به ץ گروه (هر گروه ^ سر)، كنترل رزيم غذايى

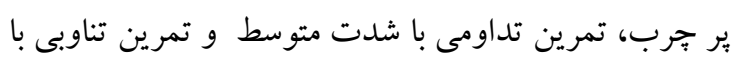

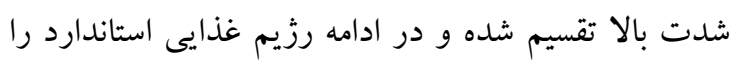

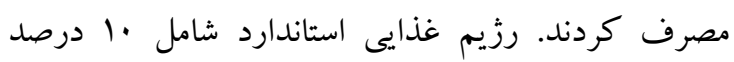

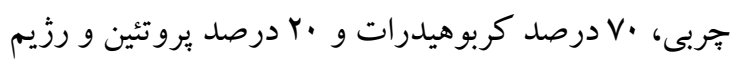

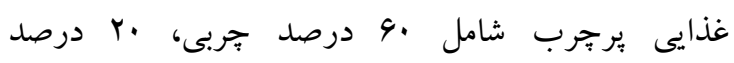

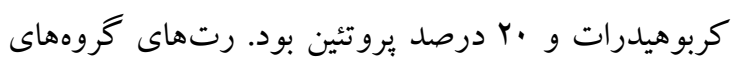
MICT و به مدت MITT

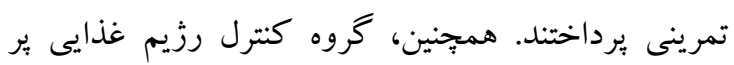
جرب در طول اين I ا هفته هيج نوع برنامه تمرينى را دريافت نكردند. در نهايت رت هاى گروه هاى MICT

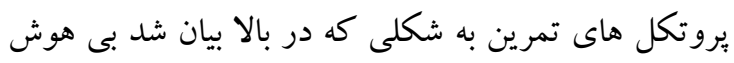

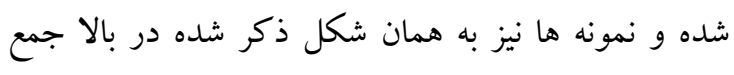

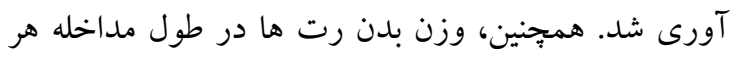

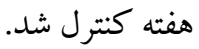

\section{يروتكل هاى تمرينى}

״س از · إهفته مصرف رزيم غذايى يرجرب، رتهائ رتهاى هر

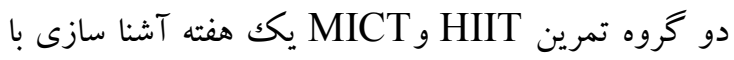

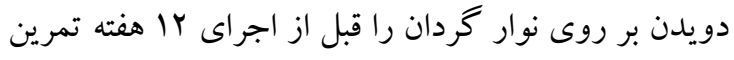

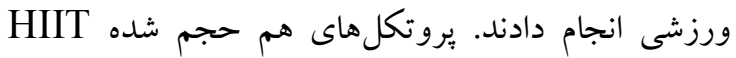
MICT,

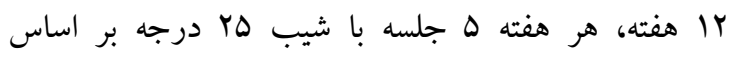
يروتكلهاى تمرينى اصلاحشده توسط هافستاد و همكاران

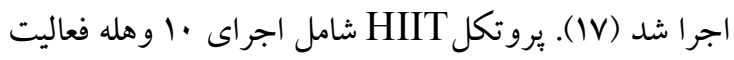

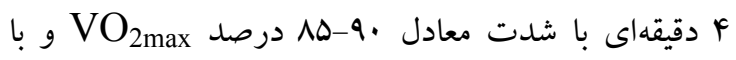

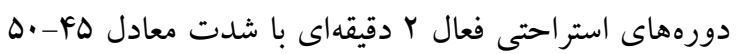
درصد VO بود كه بهصورت ييشروونده تا هفته دهم

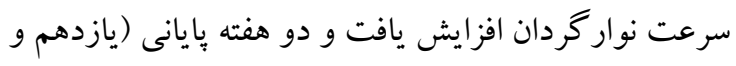

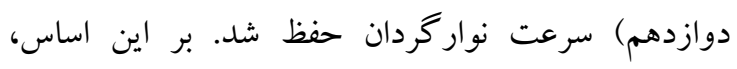

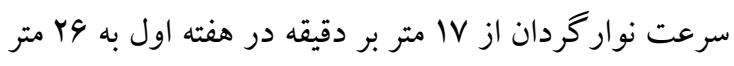

تناوبى با شدت بالا بر كاهش وزن و توده خربى از يك

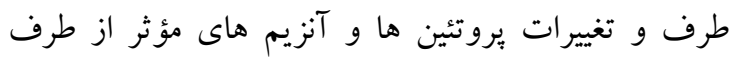

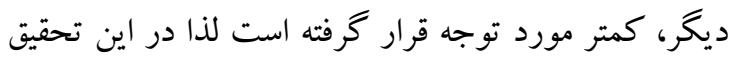

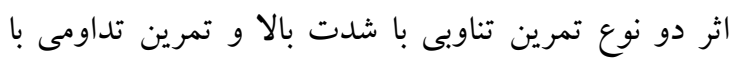

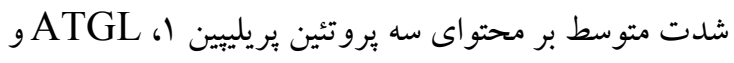

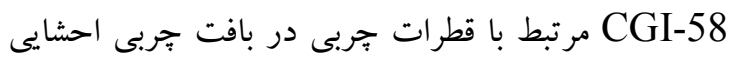
رت ها نر جاق بررسى و نشان داده شد كه تغييرات اين

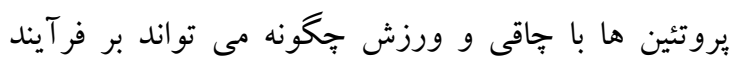
ليّيوليز و كاهش توده جربى احشايى اثر بحذارد.

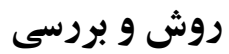

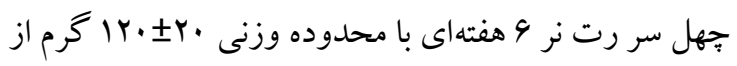
مركز تحقيقات حيوانى انستيتو پاستور (كرج، ايران)

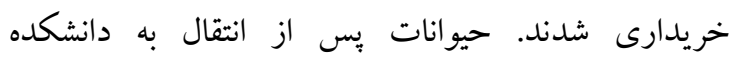

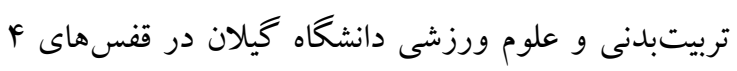

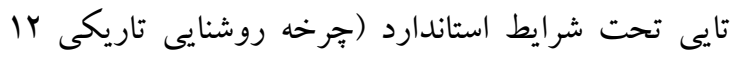

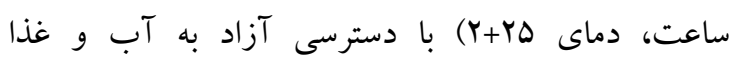

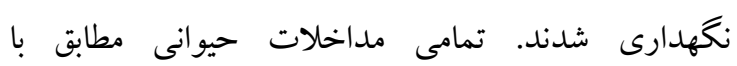
دستورالعملهاى اخلاقى مؤسسات ملى براى مراقبت و

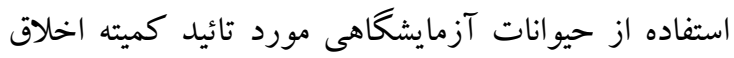

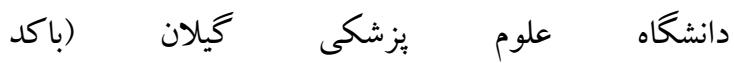
(IR.GUMS.REC.1397.091 هفته ساز كارى با محيط جديد و تغذيه از رزيم غذايى

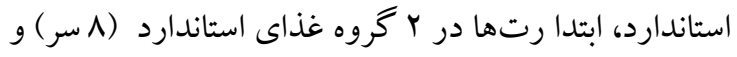

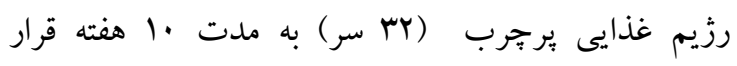

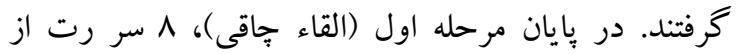

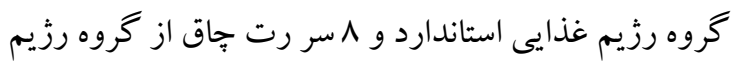
غذايى يرجرب براى بررسى اثر جاقى با استفاده از تركيب

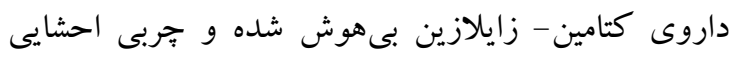

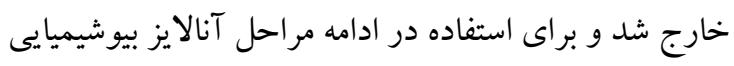

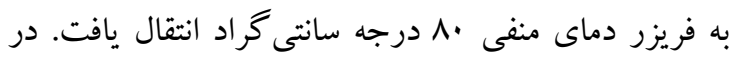

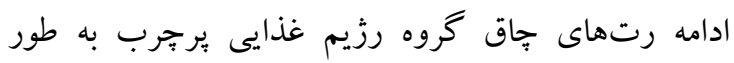


درجه سانتى گراد گذاشته شدند و سبس دريك سانتريفوز

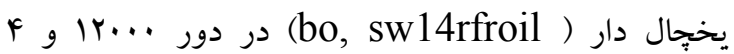
درجه سانتى گراد و به مدت · ل دقيقه سانتريفوز شد. مايع رويى جمع آورىشده و غلظت يروتئين آن با كيت تعيين

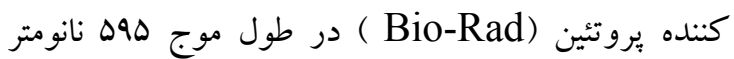
اندازهگيرى شد. درنهايت در دماى •r درجه زير صفر مرجن

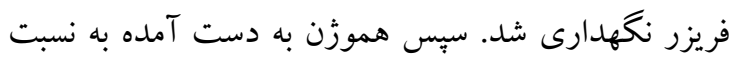

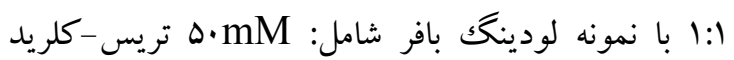

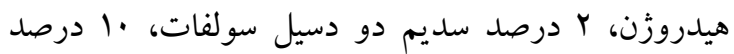

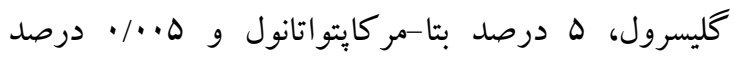

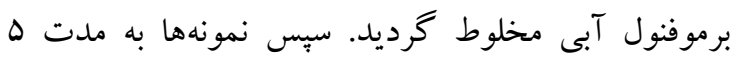
دقيقه جوشانده شد تا تمام بروتئينها كاملاً دناتوره شوند.

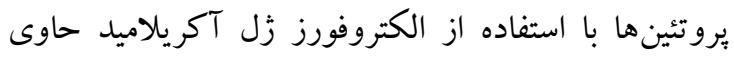
سديم دودسيل سولفات (SDS-polyacrylamide) جدا شده و به غشاى نيترو سلولز منتقل شدند. غشا به مدت 1

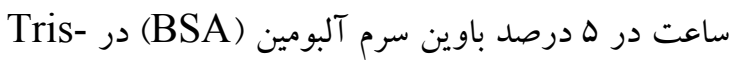
Tween 20 , Buffered Saline (TBST) انكوبه شد. روز بعد انكوياسيون در آنتىبادى ثانويه به مدت ا ساعت در دماى اتاق در \& درصد TBST انجام شد. يروتئينها با يكك واكنش شيميايى لومينسانس (ECL) و با ناس

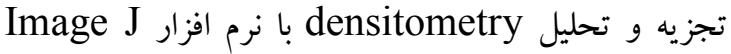
اندازهيرى شدند. براى بريلييين ا از آنتى بادى خر گوش برش

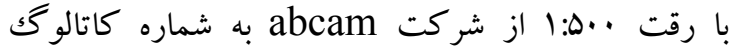
ab3526، براى ATGL از آنتى بادى موش با رقت

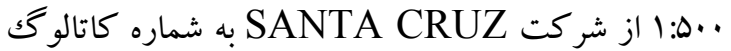
sc-365278 و براى CGI-58 از آنتى بادى موش با سعاد رقت ..ه:ا از شركت SANTA CRUZ به شماره كاتالو گs Sc-100468 استفاده شد.

\section{روش هاى آمارى}

براى توصيف داده ها از ميانگين و انحراف استاندارد

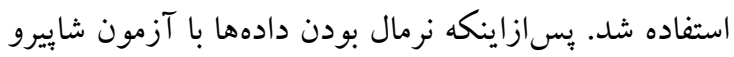

بر دقيقه در هفته دهم رسيد و دو هفته بِيانى اين سرعت حفظ شد. يروتكل MICT با شدت معادل 90-9 V HIIT بود كه مسافت طى شده با بروتكل VO

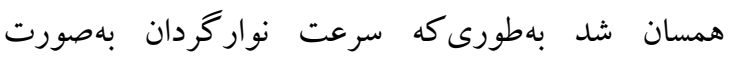
ويشرونده تا هفته دهم افزايش يافت و دو هفته بايانى حفظ

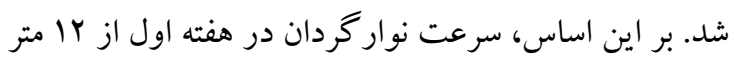

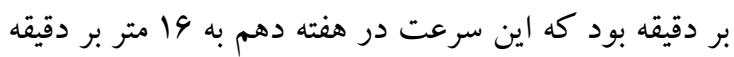

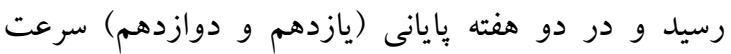

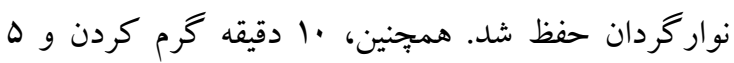
دقيقه سرد كردن با شدت پايين در ابتدا و انتهاى هر جلسه

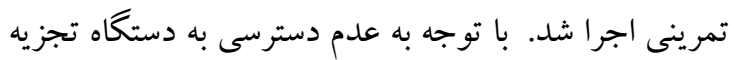

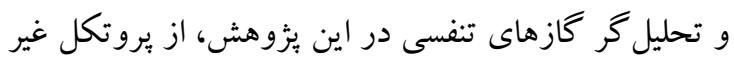

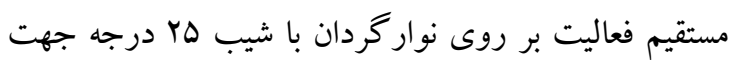

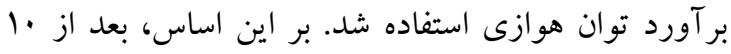

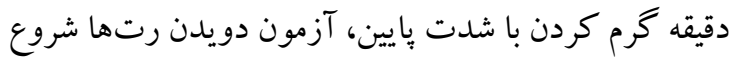

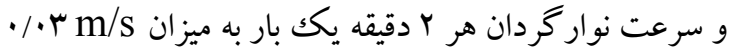

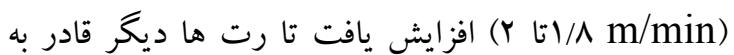
دويدن نباشند. سرعتى كه در آن VO لهدست مى آيد (IV) به عنوان سرعت حداكثر تعريف شد (V VO 11، 19). بنابراين، از V VO له عنوان معادلى از ل VO

اندازه كيرى متغير هاى بيوشيميايى

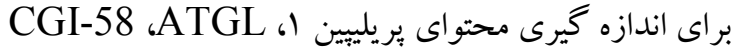
از روش وسترن بلات استفاده شد. براى استخراج يروتئين -

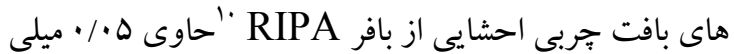
مولار بافر تريس (PH برابر A)، •1ه ميلى مولار كلريد سديم، 1 •/0 درصد EGTA، يكك درصد سديم دودسيل سولفات (SDS) به اضافه / • درصد آنتى بروتئاز كو كتيل (ROCHE)

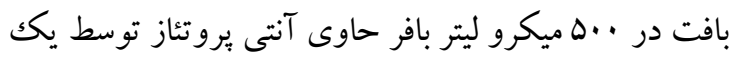

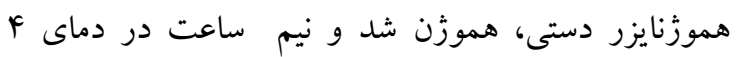

\footnotetext{
${ }^{10}$ Radio Immuno Precipitation Assay
} 
نتايج تحليل دادهها نشان داد كه ،1 هفته رزيم غذايى

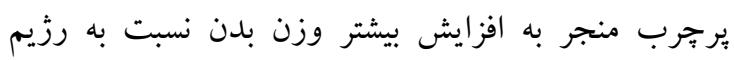

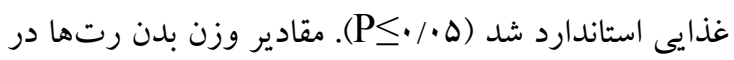

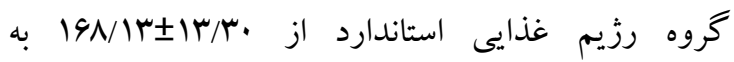
.

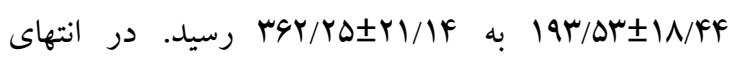
تحقيق، وزن بدن گروههاى HIIT ه درصد و MICT درصد نسبت به گروو HFD+SED بهطور غير معنىدارى كمتر بود. همجنين تفاوت معنىدارى بين گرووهاى تمرينى HIIT ور انتهاى تحقيق وجود نداشت (نمودار

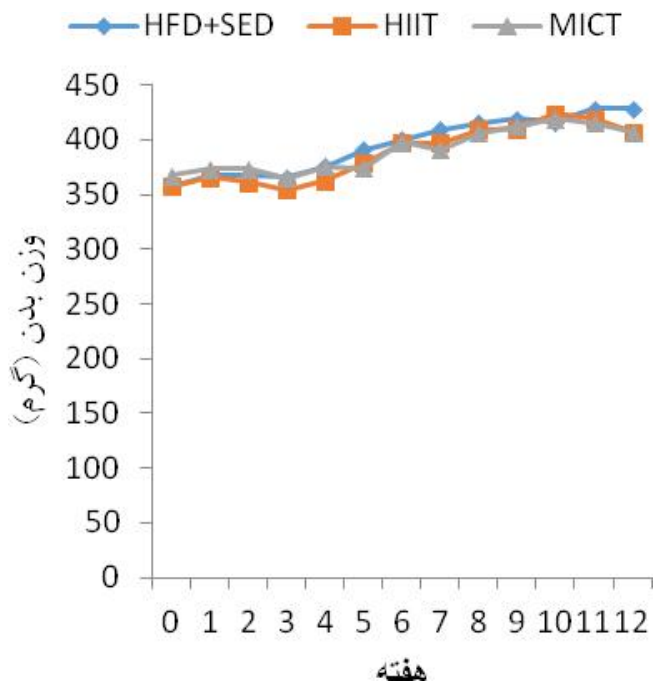

وليكك تأييد شد، جهت تعيين معنى دار بودن تفاوت ميانگين متغيرها (بريلييين ا، ATGL، تحقيق، از آزمونهاى ANOVA و تست تعقيبى LSD

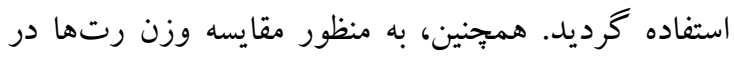

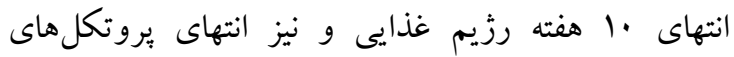

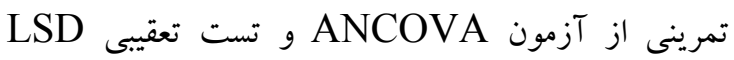

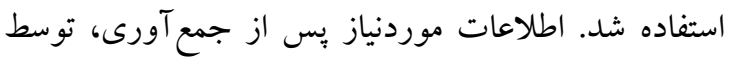

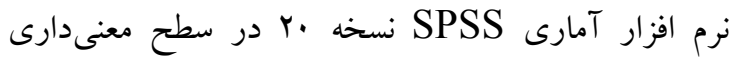

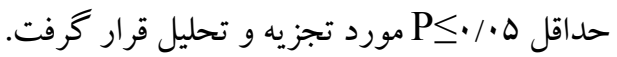

إفته ها<smiles>[AlH2]</smiles>

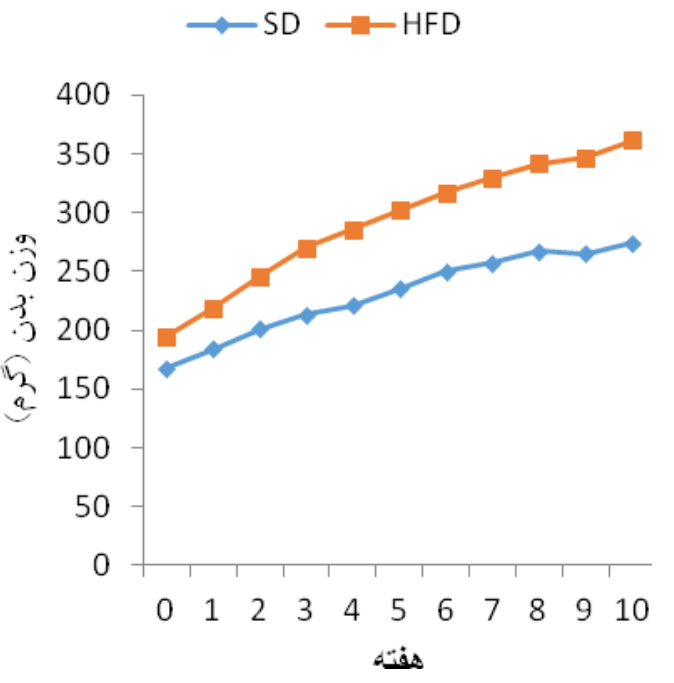

نمودار ا: وزن موشهاى صحرايى در كروههاى مختلف. الف) SD: رزيم غذايى استاندارد، HFD: رزيم غذايى يرجرب. ب) HFD+SED: كنترل

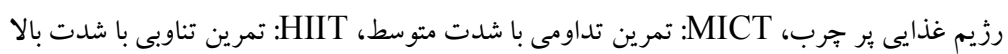

بروتئين يريليبين ا نسبت به گروه كنترل رزيم غذايى هير جرب شد. با اين حال بين گرووه هاى تمرينى تفاوت معنى دارى وجود نداشت (نمودار Y).
همجنين نشان داده شد · ا هفته رزيم غذايى برجّرب منجر به كاهش معنى دار مقدار بروتئين بريليين ا نسبت به گروه

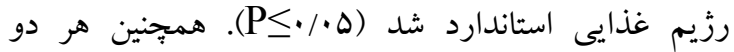
يروتكل HIIT و MICT منجر به افزايش معنى دار مقدار 


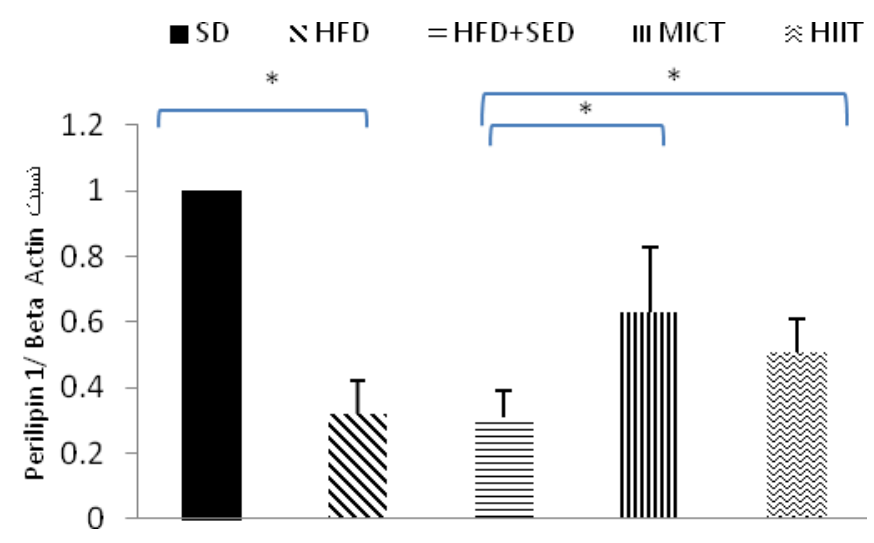

Perilipin 1

Beta Actin

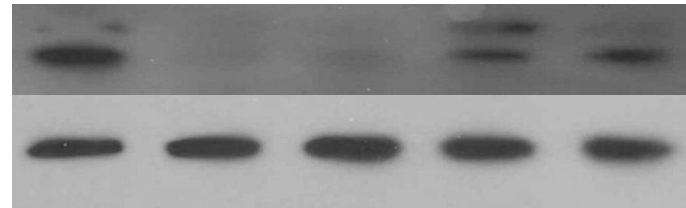

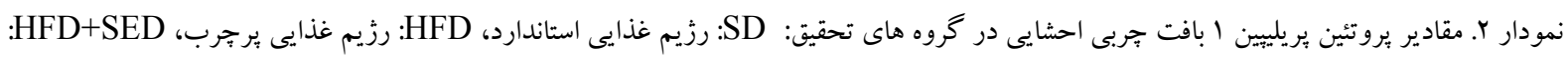

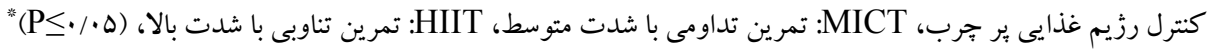

كنترل رزيم غذايى ير جرب شد. علاوه بر اين، بين گرووه

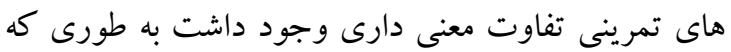

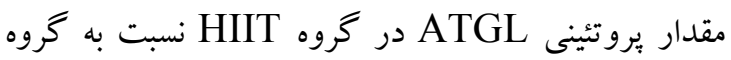
MICT, به طور معنى دارى بيشتر بود (نمودار r).
مصرف •ا هفته رزيم غذايى برجرب منجر به كاهش معنى

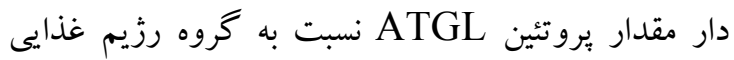

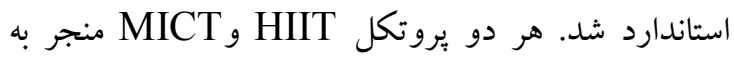
افزايش معنى دار مقدار بروتئين ATGL نسبت به گرووه

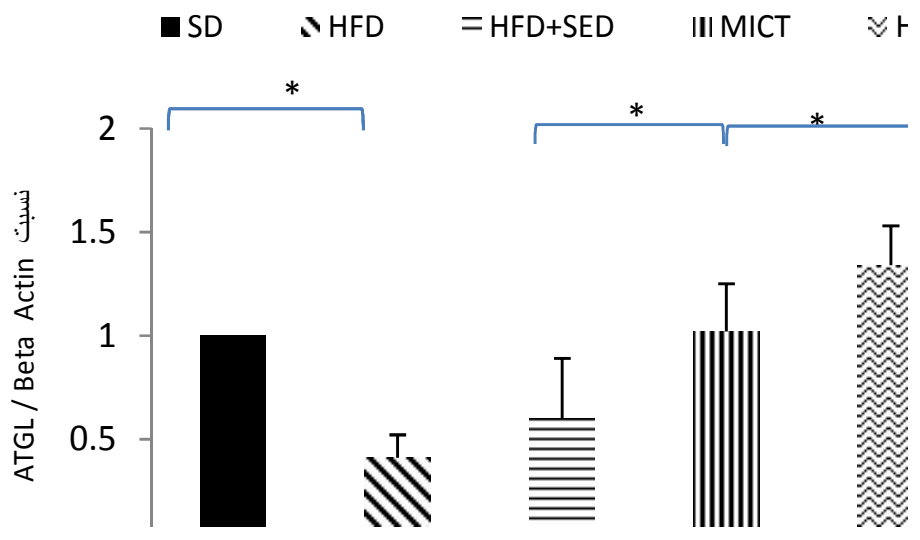

ATGL

Beta Actin

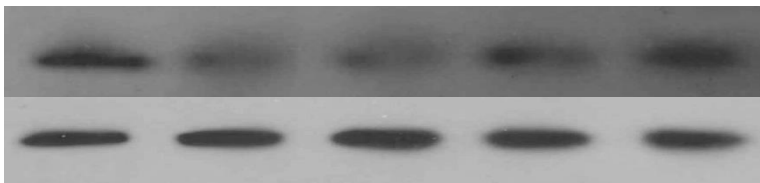

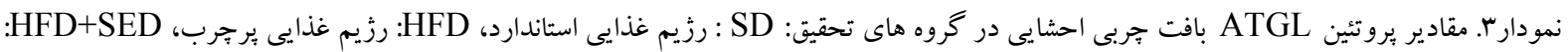

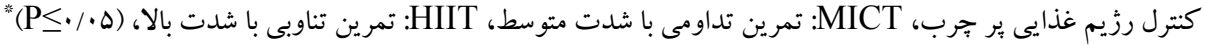


كنترل رزيم غذايى بر جرب شد. با اين حال، يروتكل

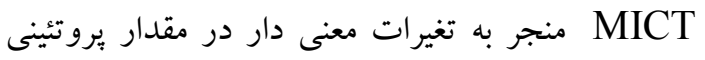
نGI-58 معنى دارى وجود نداشت (نمودار F). بر اساس نتايج تحليل داده ها • إ هفته رزيم غذايى برجرب

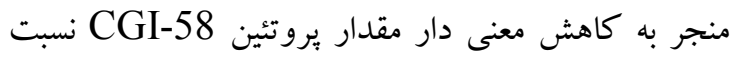

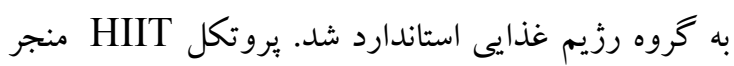
به افزايش معنى دار مقدار يروتئين CGI-58 نسبت به گرووه

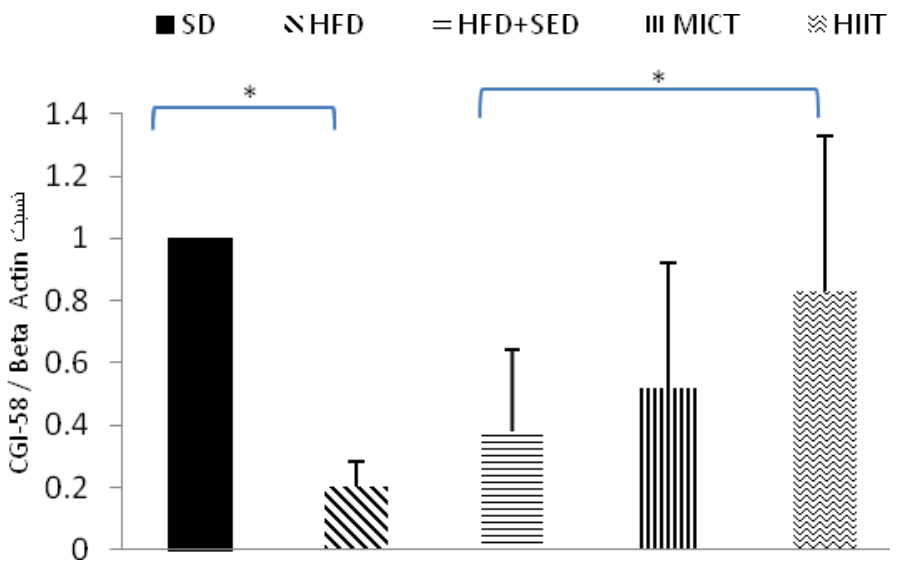

CGI-58

Beta Actin

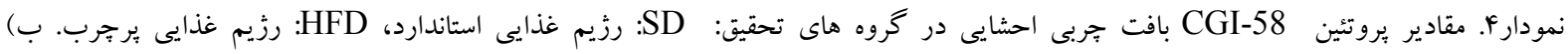

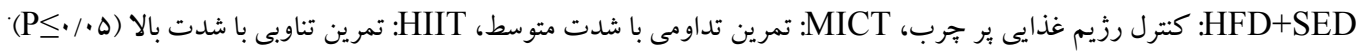

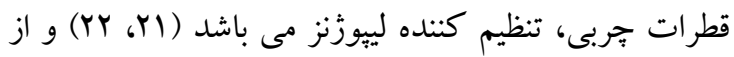
بحث هيدروليز ترى آسيل گليسيرول محافظت مى كند و ذخاير رزيم غذايى و فعاليت بدنى براى بهبود جاقى و ويشخيرى از

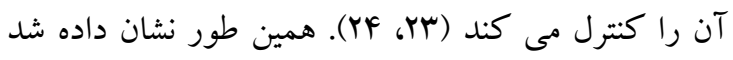

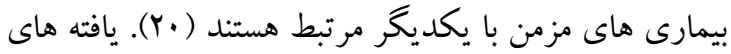
كه مقدار اين يروتئين در زمان جاقى كاهش مى يابد (11). اين تحقيق نشان داد كه رزيم غذايى بر تجرب بافي باعث افزايش علاوه بر اين بر اساس يافته هاى اين بزوهش خاقى ناشى از بافت جربى و افزايش وزن مى شود. در اين تحقيق نشان

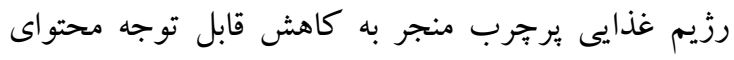

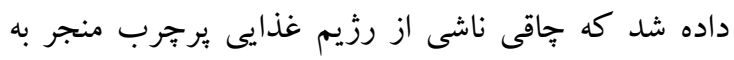

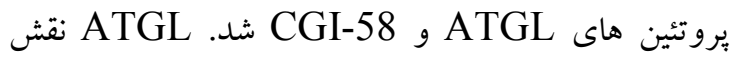

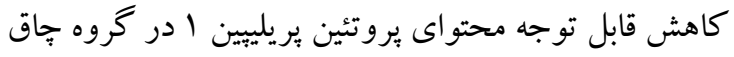
بسيار مهمى در تجزيه قطرات جربى دارد و مقدار زياد آن

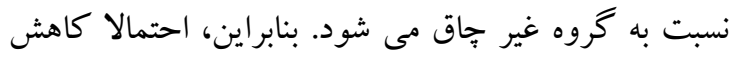
موجب كاهش اندازه ى قطرات جربى مى شود (9) (9). ميزان يريلييين ا در هنگام جاقى مى تواند باعث مهار تحقيقات نشان داده اند كه مهار ATGL باعث افز ايش

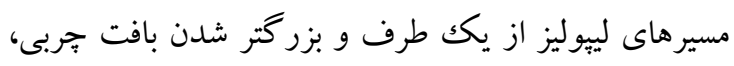

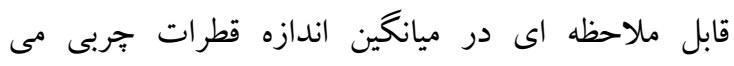
از طرف ديخر شود. در تحقيقات مختلف نشان داده شده شود(9). در آدييوسيت هاى نابالغ در كشت سلولى نشان ملين

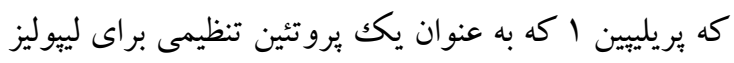

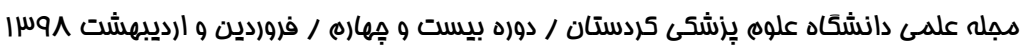


تمرينى وجود نداشت، اما يروتكل HIIT تو انست محتواى MICT به طور معنا دارى نسبت به بروتكل ATGL

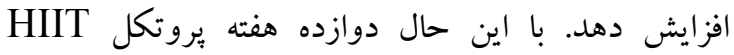
افزايش معنا دارى در محتواى CGI-58 نسبت به گرووه كنترل رزيم غذايى ير جرب ايجاد كرد اما دوازده هفته تغروتكل MICT تغييرات معنا دارى در محتواى CGI-58

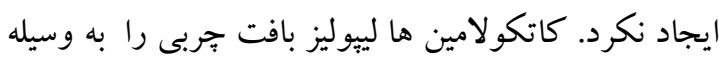
cAMP فعاليت آدنيلات سيكلاز و در نتيجه فعاليت افزايش مى دهند، كه هم زمان باعث فسفريله شدن بريلييين

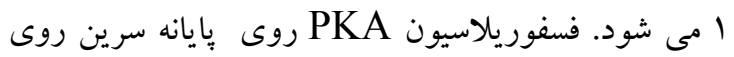

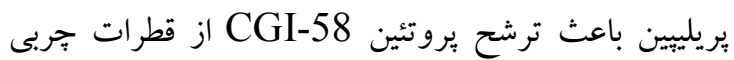
مى شود كه اين فعاليت ATGL را افزايش مى دهد. نتيجه اين اتفاق افزايش فر آيند لييوليز مى باشد (YN). در حمايت از اين تحقيق جويانك و همكارانش (11) نشان دادند

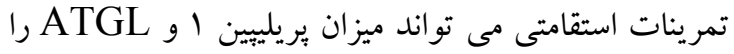
افزايش دهد بر خلاف رزيم غذايى ير خرب كه ميزان اين دو يروتئين را كاهش مى دهد. اما بر خلاف تحقيق ذكر شده كه نشان داد تمرينات استقامتى مى تواند باعث افزايش محتواى CGI-58 شود، يافته هاى اين يُزوهش نشان داد كه تنها بروتكل HIIT توانست تغييرات معنادارى در محتواى CGI-58 ايجاد كند و با اينكه بروتكل MICT تغييراتى در محتواى CGI-58 نسبت به گروه كنترل رزيم غذايى ير جرب ايجاد كرد اما اين تغييرات معنادار نبودند. به علاوه تحقيق ديخرى نشان داد كه اين بروتئين حتى مى ليى تواند در گروه هايى با رزيم غذايى بر خرب و گروه هاى تمرينى نيز كاهش بيدا كند (Y9). نتايج تحقيق حاضر نشان

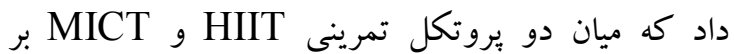

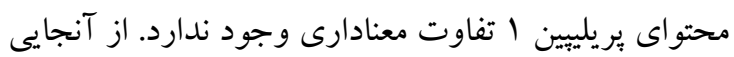

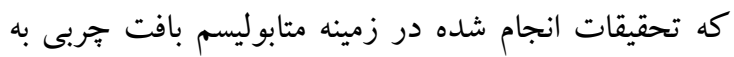

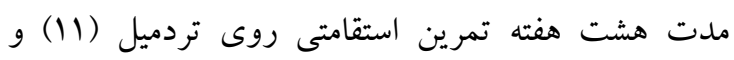

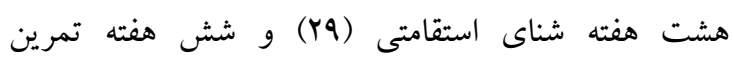
استقامتى روى تردميل (·•) انجام شده و تحقيقى در زمينه

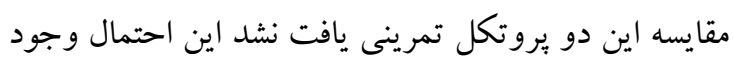

داده شده كه در صورت حذف يريلييين ا، فعاليت ATGL مى تواند محدود شود و در غياب اين بروتئين درسطح قطرات جربى، لييوليز افزايش مى يابد (YD). ATGL و تعامل آن با CGI-58 در تجزيه ترى گليسيريد بوسيله

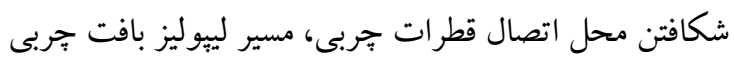

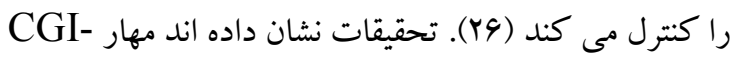

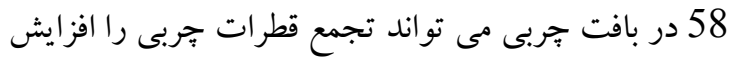

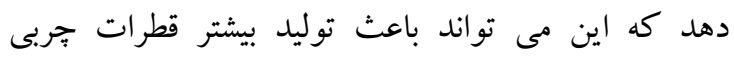

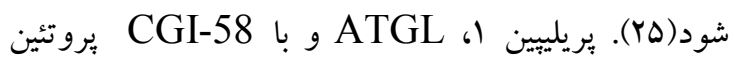
هاى مرتبط با قطر ات جربى مى باشند و نحوه ارتباط آنها با باليا يكديخر نقش مهمى در تنظيم تجمع و استفاده از جربى ها

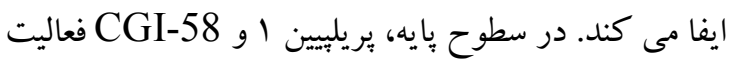

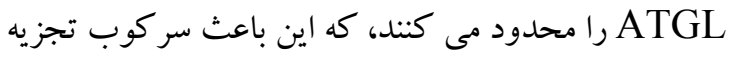
ترى آسيل كليسيرول بافت جربى به دى آسيل كليسيرول مى شود (1). بنابراين با توجه به نتايج تحقيق حاضر اين احتمال مى رود كه كاهش محتواى بريلييين ا در اثر جاقى در ابتدا مى تواند بر كاهش محتواى CGI-58 اثر بحذارد، جرا كه فسفوريله شدن يريلييين ا باعث ترشح و شروع فعاليت ATGL مى شود (•()، بنابراين كاهش يريلييين ا در زمان جاقى مى تواند عاملى باشد براى كاهش CGI-58 و و ATGL. از طرفى در غياب تحريكات هورمونى (حالت بايه)، عملكرد بريلييين ا رادر جربى هاى ذخيره شده محدود مى كند، در نتيجه ميزان

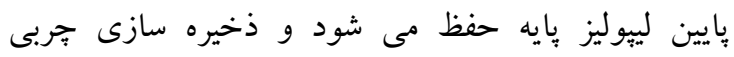
افز ايش مى يابد (YN)، بنابراين شايد بتوان جنين نتيجه گركت

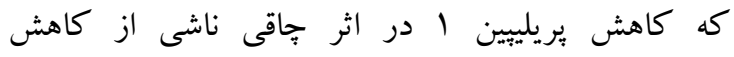
تحريكات هورمونى و بروتئين كيناز A باشد كه به دنبال آن كاهش ATGL , CGI-58 را به همر اه دارد. ورزش به عنوان يكك عامل بيشگيرى براى جاقى است؛ زيرا

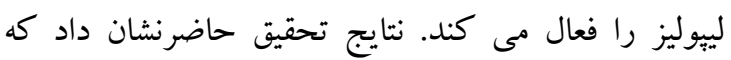

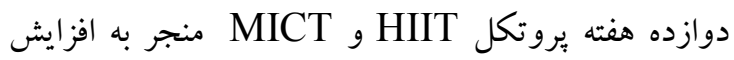

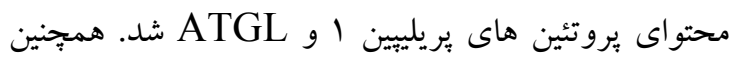

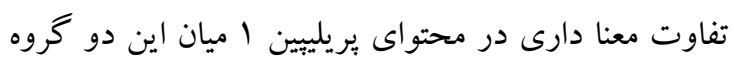




$$
\begin{aligned}
& \text { تمرينى مى تواند اثرات بهتر و حتى مشابه (با در نظر گرفتن } \\
& \text { دارد كه دليل عدم معنا دارى اين دو يروتكل تمرينى مدت } \\
& \text { مقايسه آنها بر محتواى بريلييين () را داشته باشد. } \\
& \text { زمان (دوازده هفته) انتخاب شده بر محتواى بريلييين باشد، }
\end{aligned}
$$

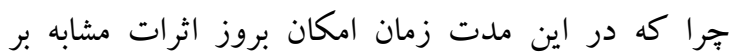

$$
\begin{aligned}
& \text { نتيجه كيرى }
\end{aligned}
$$

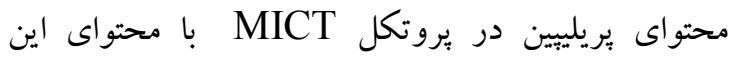

$$
\begin{aligned}
& \text { در نهايت اين تحقيق نشان داد با اينكه بروتكل HIIT و }
\end{aligned}
$$

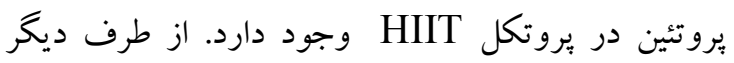

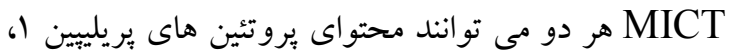

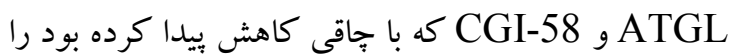

$$
\begin{aligned}
& \text { افزايش دهند و منجر به تسريع فر آيند لييوليز و كاهش ميزان }
\end{aligned}
$$

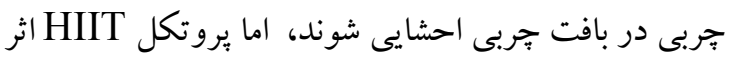

$$
\begin{aligned}
& \text { بيشترى بر روى محتواى اين بروتئين هاى كليدى فر آيند }
\end{aligned}
$$

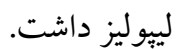

$$
\begin{aligned}
& \text { تشكر و قدردانى - ت ت ت } \\
& \text { اين مقاله از طرح رساله دكترى تخصصى يرديس }
\end{aligned}
$$

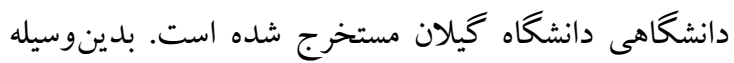

$$
\begin{aligned}
& \text { مراتب تشكر و قدردانى از مؤسسه پِاتولوزى سارا و سر كار }
\end{aligned}
$$

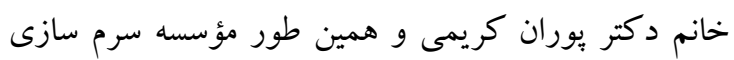

$$
\begin{aligned}
& \text { رازى و كليه همكاران اعلام مى گردد. } \\
& \text { جون در تحقيقات مختلف تغييرات فاكتورهاى مرتبط با اين }
\end{aligned}
$$

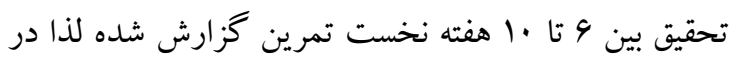

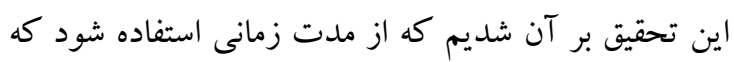

$$
\begin{aligned}
& \text { تحقيقات كمترى در آن انجام شده است. به علاوه همانطور }
\end{aligned}
$$

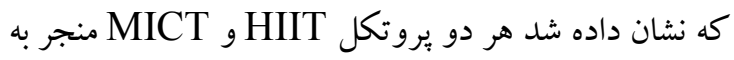

$$
\begin{aligned}
& \text { افزايش معنادارى در محتواى ATGL نسبت به گروه دوه }
\end{aligned}
$$

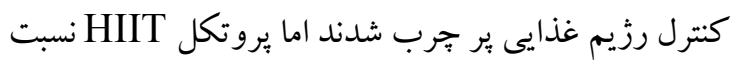

$$
\begin{aligned}
& \text { به MICT اثر بيشترى روى محتواى اين يروتئين داشت. }
\end{aligned}
$$

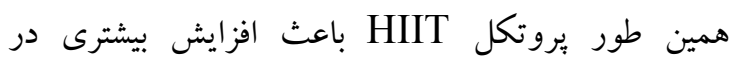

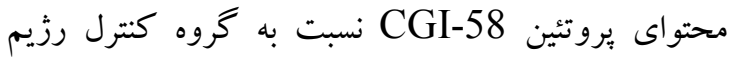

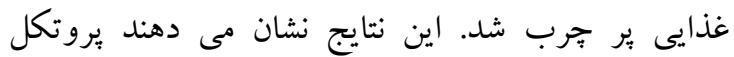

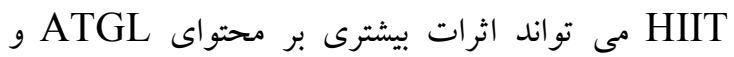

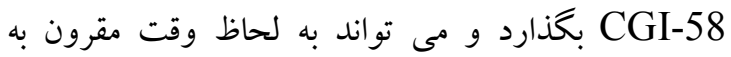

$$
\begin{aligned}
& \text { صرفه تر باشد جرا كه با مدت زمان كمتر در يكك جلسه }
\end{aligned}
$$

\section{References}

1. Kessler HS, Sisson SB, Short KR. The potential for high-intensity interval training to reduce cardiometabolic disease risk. Sports Med 2012; 42: 489-509.

2. Gong J, Sun Z, Li P. CIDE proteins and metabolic disorders. Curr Opin Lipidol 2009; 20:1216.

3. Beller M, Thiel K, Thul P J, Jä ckle H. Lipid droplets: a dynamic organelle moves into focus. FEBS Lett 2010; 584, 2176-82.

4. Wilfling F, Wang H, Haas JT, Krahmer N, Gould TJ, Uchida A, et al. Triacylglycerol synthesis enzymes mediate lipid droplet growth by relocalizing from the ER to lipid droplets. Dev Cell 2013; 24:384-99.

5. Miyoshi H, Sandra C, Endo M, Sawada T, James W, Shimizu C, et al. Perilipin overexpression in mice protects against diet-induced obesity. J Lipid Res 2010;51:975-82.

6. Sahu Osen A, Montero Moran G, Schittmayer M, Fritz K, Dinh A, Chang Y, et al. CGI58/ABHD5 is phosphorylated on Ser239 by protein kinase A: control of subcellular localization. J Lipid Res 2015;56:109-21.

7. Yang X, Heckmann B, Zhang X, Cynthia M, Liu J. Distinct mechanisms regulate ATGLmediated adipocyte lipolysis by lipid droplet coat proteins. Mol Endocrinol 2013;27:116-26. 
8. Sun Z, Gong J, Wu H, Xu W, Wu L, Gao J, et al. Perilipin1 promotes unilocular lipid droplet formation through the activation of Fsp27 in adipocytes. Nat Commun 2013;4:1594.

9. Smirnova E, Goldberg EB, Makarova KS, Lin L, Brown WJ, Jackson CL. ATGL has a key role in lipid droplet/adiposome degradation in mammalian cells. EMBO Rep 2006;7:106-13.

10. Kang S, Kim KB, Shin K. Exercise training improves leptin sensitivity in peripheral tissue of obese rats. Biochem Biophys Res Commun 2013;435:454 - 9.

11. Bae JY, Woo J, Roh HT, Lee YH, Ko K, Kang S, Shin KO. The effects of detraining and training on adipose tissue lipid droplet in obese mice after chronic high-fat diet. Lipids Health Dis 2017;16:13.

12. Burgomaster KA, Howarth KR, Phillips SM, Rakobowchuk M, Macdonald MJ, McGee SL, Gibala MJ. Similar metabolic adaptations during exercise after low volume sprint interval and traditional endurance training in humans. J Physiol 2008;586:151-60.

13. Gibala MJ ,McGee SL. Metabolic adaptations to short-term high-intensity interval training: a little pain for a lot of gain?. Exerc Sport Sci Rev 2008; 36:58-63.

14. DiPietro L, Dziura J, Yeckel CW, Neufer PD. Exercise and improved insulin sensitivity in older women: evidence of the enduring benefits of higher intensity training. J Appl Physiol 2006;100:142e9.

15. Van Aggel-Leijssen DP, Saris WH, Homan M, Van Baak MA. The effect of exercise training on beta-adrenergic stimulation of fat metabolism in obese men. Int $\mathrm{J}$ Obes Relat Metab Disord 2001;25:16e23.

16. Ogasawara J, Sakurai T, Kizaki T, Ishibashi Y, Izawa T, Sumitani Y, et al. Higher levels of ATGL are associated with exerciseinduced enhancement of lipolysis in rat epididymal adipocytes. PLoS One 2012;7: e40876.

17. Hafstad AD, Lund J, Hadler-Olsen E, Höper AC, Larsen TS, Aasum E. High-and moderateintensity training normalizes ventricular function and mechanoenergetics in mice with dietinduced obesity. Diabetes. 2013;62:2287-94.

18. Hafstad AD, Boardman NT, Lund J, Hagve M, Khalid AM, Wisløff U, et al. High intensity interval training alters substrate utilization and reduces oxygen consumption in the heart. $\mathrm{J}$ Appl Physiol 2011;111:1235-41.

19. Hoydal M, Wisloff U, Kemi O, Ellindsen O. Running speed and maximal oxygen uptake in rats and mice: practical omplications for exercise training. Eur $\mathrm{J}$ Cardiovasc Prev Rehabil 2007;14:753-60.

20. You T, Wang X, Yang R, Mary F, Gongc D, Nicklas B, et al. Effect of exercise training intensity on adipose tissue hormone sensitive lipase gene expression in obese women under weight loss. J Physiol 2001; 536: 871-7.

21. Brasaemle DL, Wolins NE. Packaging of fat: an evolving model of lipid droplet assembly and expansion. J Biol Chem 2012; 287: 2273-79.

22. Yang H, Galea A, Sytnyk V, Crossley M. Controlling the size of lipid droplets: lipid and protein factors. Curr Opin Cell Biol 2012;24:509-16.

23. Nicolaidou K, Isoldi K, Ramer N, Sarcona A. The Role of Perilipins in the Development of Obesity and Obesity-Related Disease. Top Clin Nutr 2016;31:248-56.

24. Wang Y, Sullivan S, Trujillo M, Lee M, Schneider H, Brolin R, et al. Perilipin Expression in Human Adipose Tissues: Effects of Severe Obesity, Gender, and Depot. Obes Res 2003;11:930-6.

25. Paar M, Jüngst C, Steiner NA, Magnes C, Sinner F, Kolb D, et al. Remodeling of lipid droplets during lipolysis and growth in adipocytes. J Biol Chem 2012;287:11164-73. 
26. Bezaire V, Mairal A, Ribet C, Lefort C, Girousse A, Jocken J, et al. Contribution of adipose triglyceride lipase and hormone-sensitive lipase to lipolysis in hMADS adipocytes . J Biol Chem 2009; 284:18282 -91.

27. Yamaguchi T, Omatsu N, Morimoto E, Nakashima H, Ueno K, et al. CGI-58 facilitates lipolysis on lipid droplets but is not involved in the vesiculation of lipid droplets caused by hormonal stimulation. J Lipid Res 2007;48:1078-89.

28. Miyoshi H, Perfield JW, Obin MS, Greenberg AS. Adipose triglyceride lipase regulates basal lipolysis and lipid droplet size in adipocytes. J Cell Biochem 2008;105:1430-6.

29. Farias JM, Bom KF, Tromm CB, Luciano TF, Marques SO, Tuon T, Silva LA, et al. Effect of physical training on the adipose tissue of diet-induced obesity mice: interaction between reactive oxygen species and lipolysis. Horm Metab Res 2012;45:190-6.

30. Stephenson EJ, Lessard SJ, Rivas DA, Watt MJ, Yaspelkis B, Koch LG, et al. Exercise training enhances white adipose tissue metabolism in rats selectively bred for low- or highendurance running capacity. Physiol Endocrinol Metab 2013;305:E429-E438. 